\title{
Environmental impact and recovery of the Bohai Sea following the 2011 oil spill ${ }^{\text {咨 }}$
}

\author{
Yujue Wang a , Kenneth Lee ${ }^{b}$, Dongyan Liu ${ }^{a,}{ }^{*}$, Jie Guo ${ }^{c}$, Qiuying Han ${ }^{\text {d }}$, Xihan Liu ${ }^{\text {e }}$ \\ Jingjing Zhang ${ }^{\mathrm{f}}$ \\ ${ }^{a}$ State Key Laboratory of Estuarine and Coastal Research, East China Normal University, Shanghai, 200062, China \\ ${ }^{\mathrm{b}}$ Ecosystem Science, Fisheries and Oceans Canada, Ottawa, ON, K1A 0E6, Canada \\ ${ }^{\mathrm{c}}$ Key Laboratory of Coastal Environmental Processes and Ecological Remediation, Yantai Institute of Coastal Zone Research, Chinese Academy of Sciences, \\ Yantai, Shandong, 264003, PR China \\ ' Hainan Tropical Ocean University, Sanya, Hainan, 572022, PR China \\ e Hebei Engineering Research Center for Geographic Information Application, Institute of Geographical Sciences, Hebei Academy of Sciences, Shijiazhuang, \\ 050011, PR China \\ ${ }^{\mathrm{f}}$ The Institute for Advanced Study of Coastal Ecology, School of Resource and Environmental Engineering, Ludong University, Yantai, 264025, PR China
}

\section{A R T I C L E I N F O}

\section{Article history:}

Received 27 September 2019

Received in revised form 5 March 2020

Accepted 5 March 2020

Available online 10 March 2020

\section{Keywords:}

Bohai sea

Oil spill

Penglai 19-3

Environmental impacts

Habitat recovery

\begin{abstract}
A B S T R A C T
The 2011 spill at platforms B and C of the Penglai 19-3 oil field in the Bohai Sea has been the worst oil spill accident in China. To assess long-term effects, a comprehensive monitoring program of chemical and biological variables (within a $2.2 \mathrm{~km}$ radius of the spill site) was conducted five years after the spill. Comparison of nutrient, Chl- $a$ and oil concentrations in seawater, TOC, PAHs, heavy metals concentrations within the sediments, and the abundance and biomass of macrobenthic organisms to values obtained before and after the oil spill in previous studies indicate habitat recovery has occurred within the Bohai Sea following the episodic oil release. Observed elevated oil concentration in the water column and higher concentrations of two heavy metals, five PAHs, TOC, TOC/TN and lower values of $\delta^{13} \mathrm{C}$, together with a reduction in macrobenthic biomass in near-field samples, suggest the influence of contaminants from chronic releases of oil and operational waste discharges within the vicinity of the oil platforms.
\end{abstract}

(C) 2020 Elsevier Ltd. All rights reserved.

\section{Introduction}

The Bohai Sea is a shallow water body in the northwestern Pacific Ocean, semi-enclosed by Liaodong and Shandong Peninsulas, and connects to the Yellow Sea (Huanghai) through the Bohai Strait. Its area is $77,000 \mathrm{~km}^{2}$ with an average depth of $18.7 \mathrm{~m}$. Oil exploration in the Bohai Sea started in 1965, and it is now recognized as China's second largest oil field (Guo et al., 2013) with the establishment of over 50 offshore platforms that discharged approximately 9.9 million tons of petroleum-contaminated waters in 2006 (Yuan et al., 2017).

Between June 4 and July 12, 2011, a series of spills occurred at the Penglai 19-3 and Suizhong 36-1 oil fields in the Bohai Sea. Two spill incidents occurred at platforms B and C of the Penglai 19-3 oil

\footnotetext{
This paper has been recommended for acceptance by Charles Wong.

* Corresponding author.

E-mail address: dyliu@sklec.ecnu.edu.cn (D. Liu).
}

field $\left(38.37^{\circ} \mathrm{N}, 120.08^{\circ} \mathrm{E}\right)$ on June 4 and 17 . The first occurred in a subsurface reservoir during water injection operations, causing the release of oil from a natural geological fault. This was followed by another accidental release due to the loss of well control on June 17 when operators hit an unanticipated high-pressure zone while drilling a water injection well. ConocoPhillips China (COPC) reported the release of 723 barrels of oil and 2620 barrels of mineral oil-based drilling muds into the sea over a number of days (Liu et al., 2015a). Environmental impacts were reported. Despite spill response operations, on July 11, the State Oceanic Administration reported a reduction of the "water quality ranking" of $840 \mathrm{~km}^{2}$ of surrounding waters from Grade 1 to Grade 4 , and the downgrade of an additional $3400 \mathrm{~km}^{2}$ of waters from Grade 3 to 4 . Taking into account the influx of polluted coastal waters reported by China Environment News in October 2012, the downgraded ranking applied to a total area of $5500 \mathrm{~km}^{2}$; about $7 \%$ of the whole Bohai Sea area (Li, 2013).

Oil contamination may persist in the marine environment for years after a spill. While the media typically refer to major oil spills 
as catastrophic ecological disasters, environmental recovery can be relatively swift and complete within 2-10 years (Kingston, 2002). Residence time for a system and its recovery rates can vary drastically, depending on the type of oil spilled, environmental conditions that influence its weathering rate, the habitat and species that are affected, and the level of clean-up effort. For example, as a result of genomic analysis, there is now general consensus among the scientific community that indigenous microbes significantly contributed to the removal of the oil released from the Gulf of Mexico oil spill in 2010 (Maloy, 2011), in addition to the one to five million barrels per year entering the region via natural seepage (National Research Council, 2003). Observations made following the Torrey Canyon oil spill, the Ekofisk Bravo blowout, and the Sea Empress oil spill also showed that the effectiveness of natural recovery and the resilience of ecosystems limited the extent and duration of detrimental impacts (Fingas, 2011). An analogous situation may exist within the Bohai Sea as the Penglai 19-3 oil field was found in shallow reservoirs (700-1700 m depth) within the most active fault zone in east China (Hao et al., 2009).

Recent publications have described the diversity and distribution of indigenous microorganisms within the Bohai Sea and their effective capacity to degrade petroleum hydrocarbons (Wang et al., 2013a; Li et al., 2016; Wang et al., 2016; Wang et al., 2018a). A number of environmental effects monitoring studies have also been conducted to assess the impact of the accidental release of oil at the Penglai 19-3 field, the first large-scale oil spill event in the China Seas. These programs assessed samples of seawater (Guo et al., 2013), sediment (Li et al., 2015) and biota (Lei et al., 2015; Zhou et al., 2016), in addition to the fisheries and mariculture industry (Pan et al., 2015). The spill raised concentrations of oil in the seawater up to 40.5 times above background levels, brought abnormally high Chlorophyll- $a$ (Chl- $a$ ) concentrations, altered the distribution of red tides, impacted the benthic foraminifera and macrobenthic community structure, and caused ecological damage to fisheries and mariculture (Guo et al., 2013; Lei et al., 2015; Pan et al., 2015; Cheng et al., 2016; Zhou et al., 2016). These initial post-spill studies mainly focused on impacts to individual components rather than taking a comprehensive ecosystem evaluation approach that includes the analysis of physical, chemical and biological factors within the seawater and sediment environment.

To evaluate recovery five years after this major oil spill event and the impacts of ongoing oil exploration and production within the Bohai Sea, in 2016, integrated analyses of parameters in seawater, sediment and biota were conducted at sites to a $2.2 \mathrm{~km}$ radius around the Penglai 19-3 oil drilling platforms B and C, and comparison between these results and previous studies were made. The study will not only help us understand the environmental recovery from the oil spill event within the Bohai Sea, but could provide insights into the study of environmental impacts of crude oil releases in other parts of the world.

\section{Materials and methods}

\subsection{Sample collection}

17 locations in a radial pattern out to a distance of $2.2 \mathrm{~km}$ from the Penglai 19-3 platforms B and C were selected for collecting water and sediment samples (Fig. 1a). From May 17 to 20, 2016, temperature, salinity and $\mathrm{pH}$ values were measured (YSI 6600V2, USA) in situ at three depths, surface (0-0.3 m), middle (14.0-14.3 $\mathrm{m}$ ) and bottom (27.5-28.0 m). Seawater samples at the three depths were collected using a 5 L Go-Flo bottle. A $500 \mathrm{~mL}$ subsample of seawater was preserved with $5 \mathrm{~mL}$ of $25 \%(\mathrm{v} / \mathrm{v})$ sulphuric acid in a glass bottle for quantitative oil analysis. Seawater samples $(500 \mathrm{~mL})$ for nutrient analysis were filtered through cellulose acetate membranes (Whatman, $0.45 \mu \mathrm{m}$ ) in situ and immediately frozen $\left(-20^{\circ} \mathrm{C}\right)$. For Chl- $a$ extraction and quantification, three replicate $200 \mathrm{~mL}$ seawater samples were collected on Whatman GF/F filters under low vacuum, and then the filter was stored at $-20^{\circ} \mathrm{C}$ until analysis. Sediments were recovered with an Ekman-Birge bottom sampler (Hydro-Bios Apparatebau $\mathrm{GmbH}$, Germany). The top $10 \mathrm{~cm}$ of undisturbed sediment within the bottom sampler was collected for heavy metal analysis with a corer fabricated from a $1.5 \mathrm{~cm}$ diameter plastic syringe. Corresponding subsamples for total organic carbon (TOC), total nitrogen (TN), $\delta^{13} \mathrm{C}$, and polycyclic aromatic hydrocarbons (PAHs) analyses were collected with stainless steel corers (10 cm diameter) from the top $10 \mathrm{~cm}$ of undisturbed sediment. Two replicate sediment samples collected with a van Veen grab $\left(0.25 \times 0.25 \mathrm{~m}^{2}\right.$ bite area) were sieved through a $0.5 \mathrm{~mm}$ mesh to isolate macrobenthic organisms which were preserved in $80 \%$ ethanol for laboratory identification.

\subsection{Sample analysis}

(see supplementary methods).

\section{Results and discussion}

\subsection{Background information}

Water depth in the study area (extending out $2.2 \mathrm{~km}$ from the release point of the 2011 oil spill) was $27.9-28.6 \mathrm{~m}$ with an average of $28.2 \mathrm{~m}$ (Fig. 1b). During the sampling period, the wave height of the study area was $0-1 \mathrm{~m}$, sea surface current was $0-0.2 \mathrm{~m} / \mathrm{s}$, and current at $5 \mathrm{~m}$ and $10 \mathrm{~m}$ was $0-0.3 \mathrm{~m} / \mathrm{s}$. Sea temperature was $11.6-13.6{ }^{\circ} \mathrm{C}$ in the surface layer $(0-0.3 \mathrm{~m}), 10.1-11.2{ }^{\circ} \mathrm{C}$ in the middle layer (14.0-14.3 $\mathrm{m}$ ), and $10.0-10.2{ }^{\circ} \mathrm{C}$ in the bottom layer $(27.5-28 \mathrm{~m})$. There was limited variance in the values for salinity and $\mathrm{pH}$ within the study area during the sampling period. Salinity was 33.7-33.9 ps $\mu$ in the surface and $33.9 \mathrm{ps} \mu$ in the middle and bottom layers. Seawater $\mathrm{pH}$ was $7.98-8.07$ in the surface layer, 8.05-8.08 in the middle layer and 8.02-8.07 in the bottom layer. The vertical distribution of temperature and salinity indicated weak vertical mixing between surface and bottom layers.

\subsection{Effects within the water column}

\subsubsection{Nutrients, Chl-a and oil concentrations in seawater}

The concentrations and distribution for dissolved inorganic nitrogen (DIN: $\mathrm{NO}_{3}^{-}+\mathrm{NO}_{2}^{-}+\mathrm{NH}_{4}^{+}$), dissolved organic nitrogen (DON), dissolved inorganic phosphorus (DIP), and dissolved silicate (DSi) are illustrated in Table 1 and Fig. 2a-l. Within the current study site, DIN concentrations increased with depth, and DIP concentrations also increased slightly from surface to bottom. DSi concentrations were relatively higher in the middle layer and lower at the surface and bottom (Table 1). Higher DIN and DIP observed in bottom waters are likely the result of nutrient recycling within the benthic zone (Liu et al., 2004; Liu et al., 2014a). Elevated concentrations of nutrients were observed at Stations 0,1,2 and 3 in the surface layer in close proximity to platforms B and $\mathrm{C}$, and in the middle and bottom layers at stations in the north and south of the study area (Fig. 2a, d, g, j).

Chl- $a$ concentrations exhibited a distinct increase with water depth. Relatively higher Chl- $a$ concentrations were generally observed $\mathrm{N}-\mathrm{NW}$ of the oil spill release site at all depths (Fig. 2o-m). Nutrients, light intensity, and temperature are known environmental factors that influence the growth of phytoplankton. The vertical distribution of Chl- $a$ indicate that light intensity and temperature were not dominant factors. Lower Chl- $a$ concentrations observed within in the surface seawater might be associated 


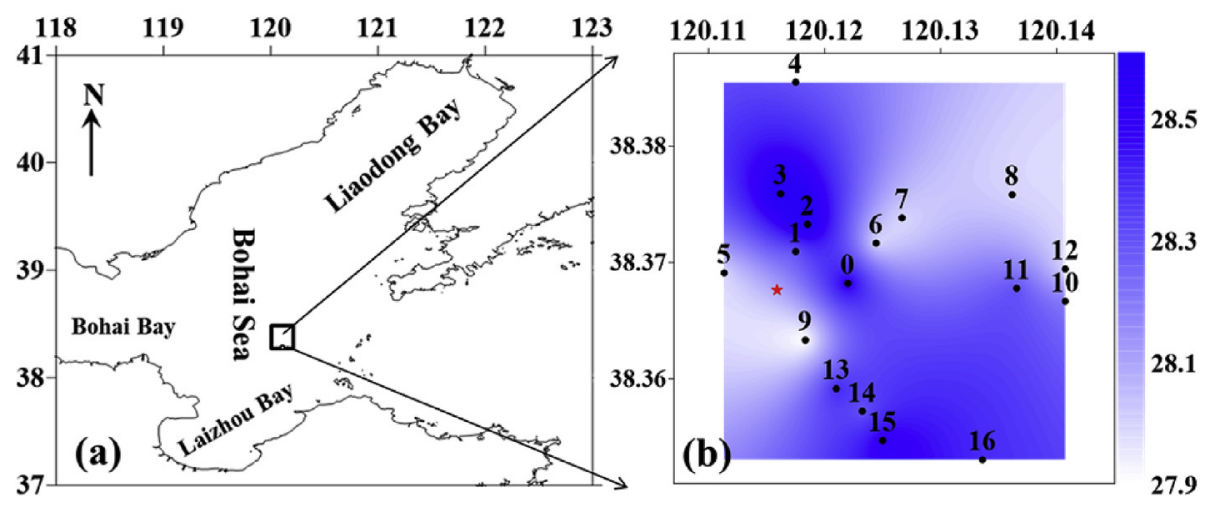

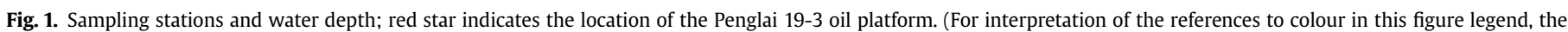
reader is referred to the Web version of this article.)

with limited nutrient levels in comparison to the higher Chl- $a$ concentrations observed in the bottom layer that may have benefited from the release of nutrients from the sediment (Liu et al., 2014a; Lee et al., 2015).

The concentration of oil within recovered seawater samples was often used as an indicator of residual oil from the spill. The mean concentrations of oil in the water column during our 2016 monitoring program were $28.3 \mu \mathrm{g} / \mathrm{L}$ in the surface layer, $27.7 \mu \mathrm{g} / \mathrm{L}$ in the middle and $29.5 \mu \mathrm{g} / \mathrm{L}$ in the bottom (Table 1 ). Spatial distribution of oil concentrations, however, showed an obvious trend of higher near-field oil concentrations in all three layers toward the west of the study area close to the platform, increasing from surface $(36.1 \mu \mathrm{g} / \mathrm{L})$ to bottom $(45.3 \mu \mathrm{g} / \mathrm{L})$ (Fig. $2 \mathrm{p}-\mathrm{r}$ ).

\subsubsection{Water column effects evaluation based on the comparison to previous studies}

Spilled oil at sea undergoes natural weathering processes that include spreading, mixing, evaporation, dissolution, dispersion, biodegradation, photo-oxidation, and sedimentation (Sharma, 1999; Cerniglia and Perry, 2010; Dubinsky et al., 2013). Typically oil spilled at sea initially spreads over the water surface as a slick a few millimeters thick and the volatile components in crude oil rapidly evaporate after spillage. Wind and currents disperse the oil slick over a greater area (Kingston, 2002). The spilled oil from the Penglai 19-3 platforms has characteristics of high-density, high viscosity and high colloid content (Guo et al., 2013), which may have suppressed its rate of spreading and evaporation following its accidental release. Furthermore, the rate of oil dissolution and dispersion within the water column may have been constrained by relatively weak water currents within the study area (Guo et al., 2013; Wang et al., 2017).

Nutrients, Chl- $a$ and oil concentrations before, during and after the oil spill accident are listed in Table 1. DIN concentrations in this study were comparable to that of May 1998-1999 before the oil spill and in May 2012 after the oil spill, however, the vertical distribution differed from that in 2012. DIP concentrations were much higher than that observed in May 2012 but close to those measured in 1998-1999 (Table 1, Yu et al., 2000; Liu et al., 2014a). Biodegradation by indigenous microorganisms is a key factor in the natural attenuation of oil spilled at sea. It is well known that indigenous oil degrading marine bacteria rapidly adapt to spilled petroleum hydrocarbons and that their optimal growth rates may be limited by nitrogen and phosphate (Atlas, 1981). In May 2012, the decreasing DIN concentrations from surface to bottom and the lower DIP concentrations might have been related to the consumption of these nutrients due to biodegradation of petroleum hydrocarbons within the bottom layer. Based on the vertical distribution of DIN and increased DIP concentrations, this consumption was no longer evident in 2016. The relatively lower DSi concentrations in May 2016 was mainly due to diatom consumption and the reduction of freshwater discharge into the Bohai Sea in spring.

The accidental release of oil in 2011 may have had an initial impact zone that exceeded $3400 \mathrm{~km}^{2}$. The retention of oil slicks around the source of the spill during this period was thought to be the cause of an abnormal shift in the concentration and distribution of Chl- $a$ in the Bohai Sea, with concentrations reaching $13.66 \mu \mathrm{g} / \mathrm{L}$ at platform area, including the induction of harmful algal blooms, compared to less than $5 \mu \mathrm{g} / \mathrm{L}$ in the surrounding area (Guo et al., 2013). The Chl- $a$ concentrations in this study were slightly lower to Chl- $a$ concentrations in the central Bohai Sea in 2014 and 2016 (Table 1, Liu et al., 2014a; Wang et al., 2018b). Based on reported concentration and the spatial distribution data for Chl- $a$ within the central Bohai Sea (including the current study area) from June to July, 2016, abnormal Chl- $a$ concentrations were not detected at the study area (Fig. 2 m- o, Wang et al., 2018b).

According to previous studies in 2006-2007, oil concentrations of surface seawater in the Bohai Sea averaged $25.2 \mu \mathrm{g} / \mathrm{L}$ in spring and $30.5 \mu \mathrm{g} / \mathrm{L}$ in summer, with the maximum values being $48.4 \mu \mathrm{g} / \mathrm{L}$ and $49.6 \mu \mathrm{g} / \mathrm{L}$ in these seasons respectively (Huo et al., 2011). Following the Penglai 19-3 spill, substantially higher concentrations of oil were observed in seawater samples collected near the bottom over a four month period until October 2011. The loss of the oil gradient with depth disappeared over time due to the weathering of the oil and dispersion by currents (State Oceanic Administration, 2012). Our results, indicate that five years after the spill, oil concentrations were within the range of reported values from previous studies, and that sea water quality in the study area met the first and second class of seawater quality standards for oil concentration ( $50 \mu \mathrm{g} / \mathrm{L}$, Standards of Seawater Quality, P. R. China) (Table 1). In fact, oil concentrations in our study were comparable to most Chinese coastal waters of the Southern Yellow Sea, East Sea and South Sea, and were actually lower than the Changjiang River (Yangtze River) estuary, Dongshan and Quanzhou Bay of the East China Sea, the Bohai Strait, and the Northern Yellow Sea (Yuan et al., 2005; Huo et al., 2011; Ding, 2012; Yang, 2013).

In a summary, five years after the oil spill, in comparison to baseline data prior to the spill, there is no evidence of residual oil significantly changing nutrient concentrations within the Bohai Sea. The spilled oil had already been biodegraded or dissipated to extremely low concentrations. The differences observed in the spatial distributions of oil and Chl- $a$ concentrations within the study area are likely due to chronic inputs of oil from ongoing routine exploration and production operations. 
Table 1

Comparison of parameters in the study area at different periods.

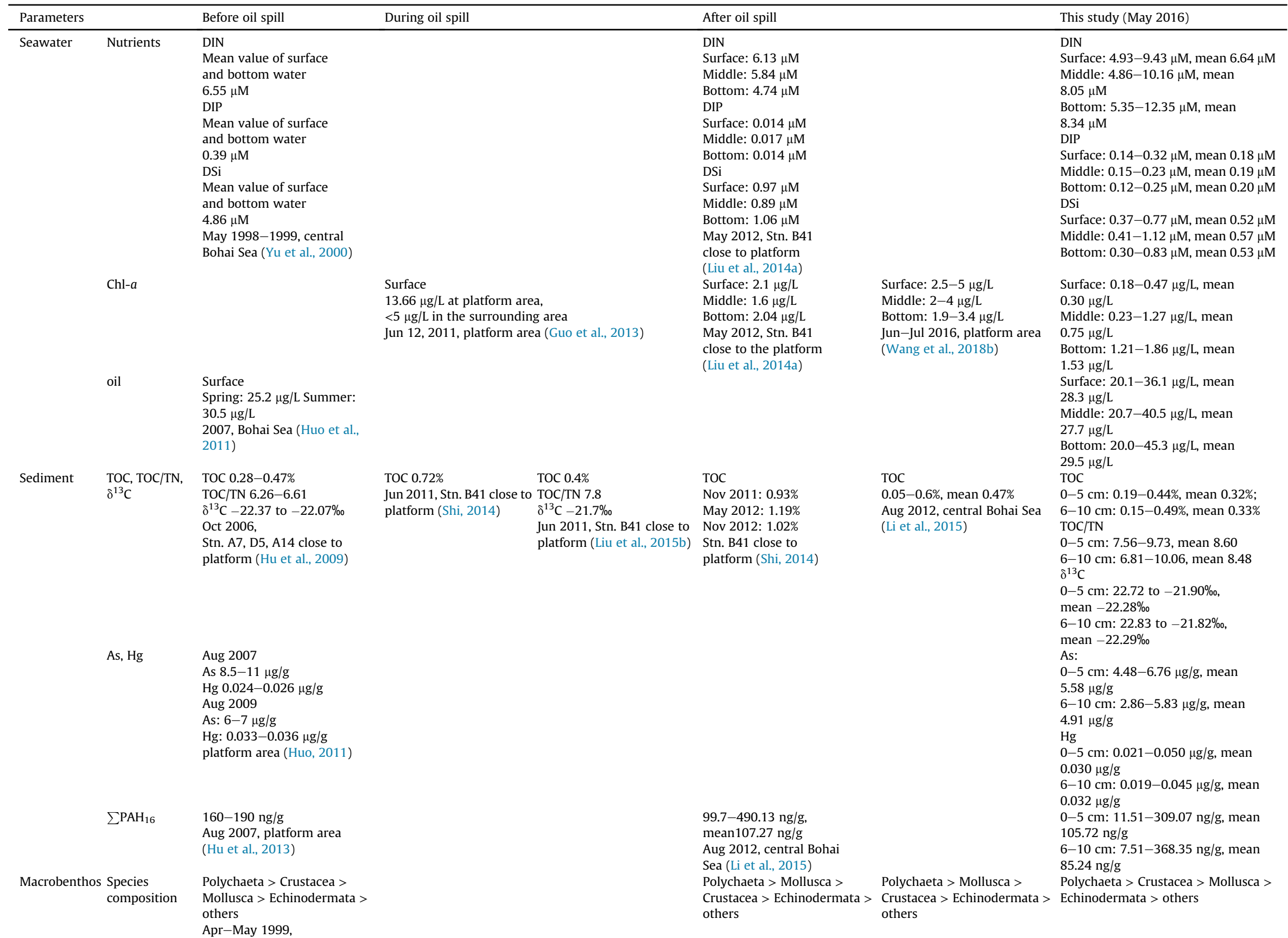




\subsection{Effects within the sediments}

Although the marine environment can readily attenuate spilled oil over time, seafloor sediment samples have been used to provide evidence of oil spills from tankers and operational releases from drilling platforms (Wei et al., 2015; Xu et al., 2013). In addition to being removed by biodegradation and photooxidation processes, as it is being physically dispersed following its release from a point source, a fraction of the spilled oil could interact with drilling muds and other suspended inorganic (e.g. mineral fines) and organic matter (e.g. plankton and their extracellular products) to form oil-mineral aggregates (OMA) and marine oil snow (MOS) (Bragg and Yang, 1995; Quigg et al., 2019) that could effectively facilitate the transport of oil to the seabed (Lee and Stoffyn-Egli, 2001; Niu et al., 2011; Daly et al., 2016). Evidence from monitoring programs associated with offshore oil exploration and production activities and oil spills has demonstrated that a significant amount of oil and drilling muds may be transported to the seabed as a result of operational oil exploration and production activities and accidental spills (Candler et al., 1995; Quigg et al., 2019). Based on a sedimentation rate within the range of $0.29-0.5 \mathrm{~cm} / \mathrm{a}$ for the study area within the Bohai Sea, residues of spilled oil or drilling mud would be trapped within the top $1.5-2.5 \mathrm{~cm}$ of sediments, if bioturbation activity was limited (Hu et al., 2011). Thus, to trace the effects of the oil spill and oil exploration activities, sediments in this study were recovered for analysis of PAHs, TOC, TN, $\delta^{13} \mathrm{C}$ and heavy metals at 0-5 cm and 6-10 cm depth for environmental comparison before and after the 2011 oil spill accident. Related parameters of sediment around the platform in previous studies before, during and after the oil spill are also shown in Table 1 to better illustrate the environment recovery.

\subsubsection{TOC, TOC/TN and $\delta^{13} \mathrm{C}$}

TOC is often used to express the content of organic matter in sediment. In our study, TOC values at $0-5 \mathrm{~cm}$ and $6-10 \mathrm{~cm}$ were comparable to TOC of sediment samples before the oil spill ( $\mathrm{Hu}$ et al., 2009), slightly lower than samples taken during the accident by Liu et al. (2015b) and after the accident in Li et al. (2015), and much lower than samples taken during and after the accident in the study of Shi (2014) (Table 1). The reason for the higher TOC values in Shi (2014) might be that potassium dichromate oxidation was used for TOC analysis as compared to hydrochloric acidization and elemental analyzer analysis used in the other studies. Nevertheless, the Shi (2014) still indicated an increase of TOC within one year of the oil spill. As a result, the relatively lower TOC values in our study compared to that observed in 2011-2012 indicated that the impact from the oil spill almost disappeared after five years. Spatial distribution of TOC showed higher nearfield TOC values in the surface layer sediments $(0-5 \mathrm{~cm})$ $(>0.40 \%)$ together with lower values at same place in the bottom layer sediments $(6-10 \mathrm{~cm}$ ) (Fig. $3 a$ and b). The higher near-field TOC at the surface is likely the result of changes in biological production and/or ongoing oil exploration and production.

Both the TOC/TN ratio and $\delta^{13} \mathrm{C}$ have been used to determine the source of organic matter. TOC/TN ratios for marine organic matter range between 6.7 and 10.1, and $>15$ for terrigenous organic matter (Meyers, 1994; Cifuentes et al., 1996). Typical $\delta^{13} \mathrm{C}$ values for marine phytoplankton are about -22 to $-19 \%$ (Owens, 1987; Wada and Hattori, 1991), while $C_{3}$ terrestrial plants have $\delta^{13} \mathrm{C}$ around $-27 \%$ and $\mathrm{C}_{4}$ plants between -17 and $-9 \%$ (Cai et al., 1988; Boutton, 1991). The TOC/TN ratios and the $\delta^{13} \mathrm{C}$ values in our study indicated a mixture of organic matter from marine and terrigenous sources, with the dominant source being marine organic matter (Table 1 ; Fig. $\mathbf{c}-\mathrm{f}$ ). Our study area is in the 


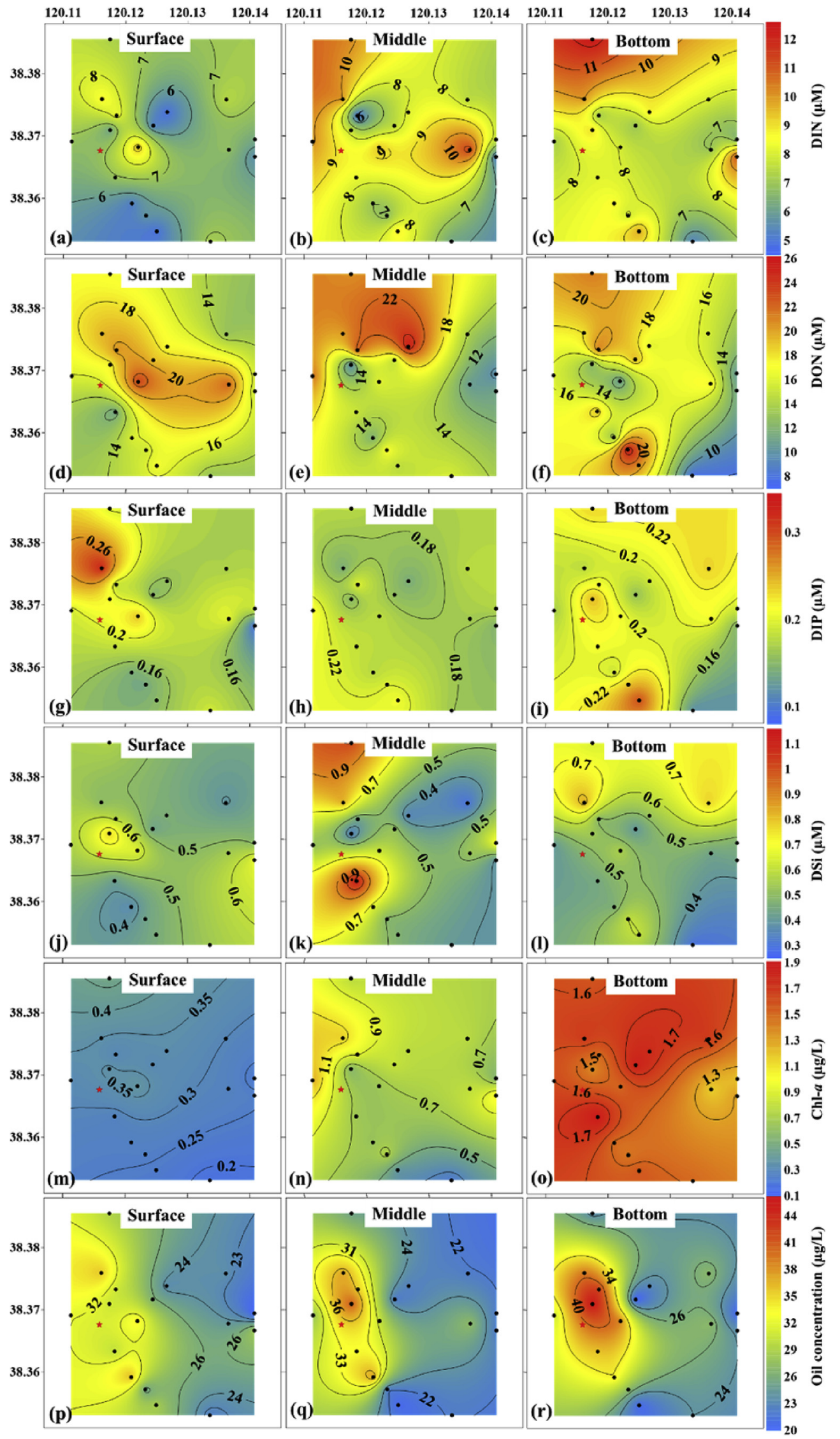

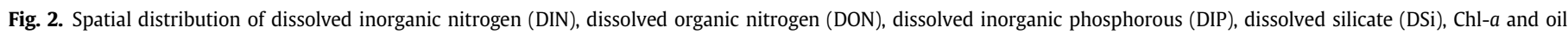
concentrations at three depths. 

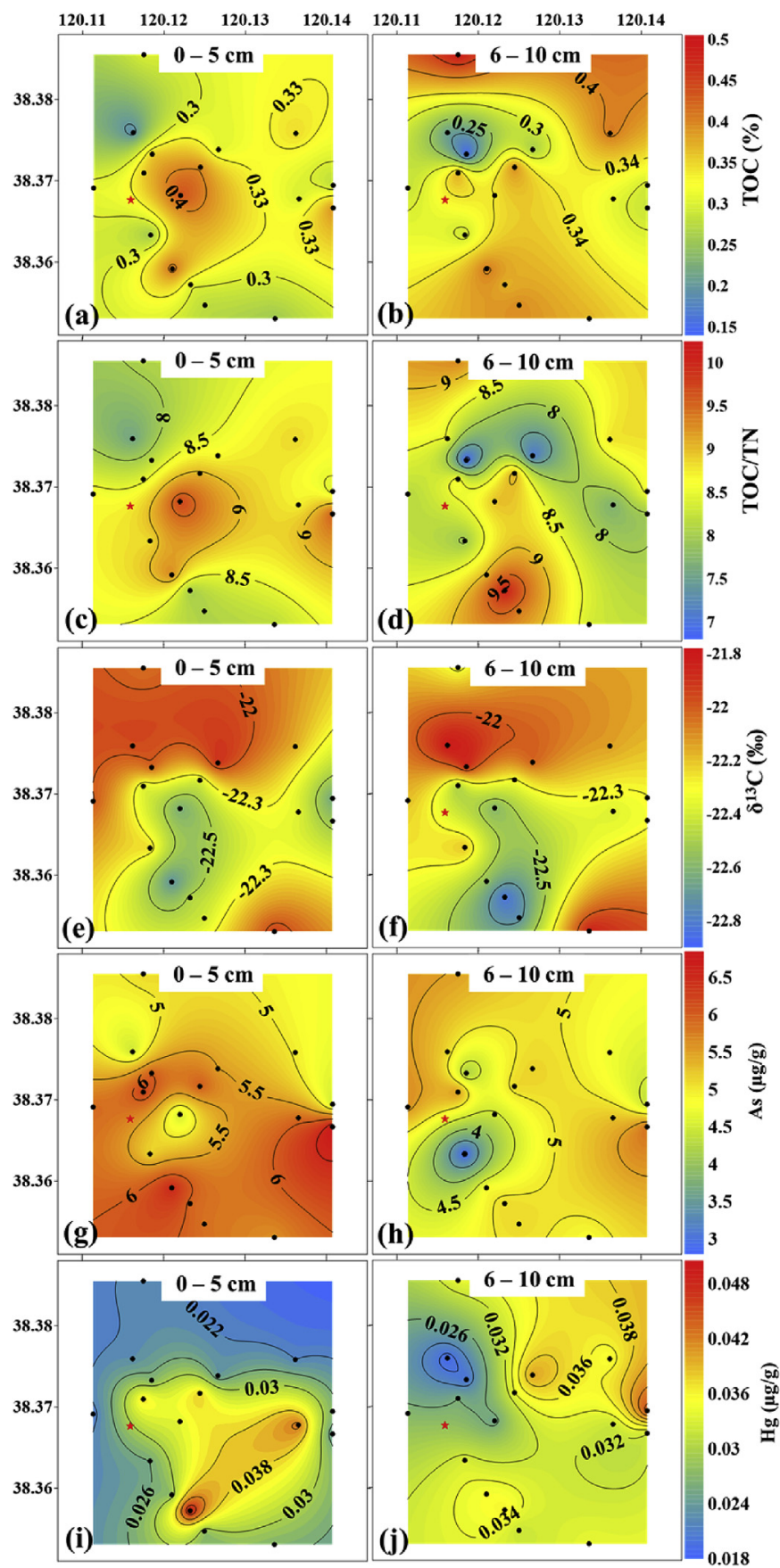

Fig. 3. Spatial distribution of TOC, TOC/TN, $\delta^{13} \mathrm{C}$ and two heavy metals (As and $\mathrm{Hg}$ ) at sediment depths of $0-5 \mathrm{~cm}$ and $6-10 \mathrm{~cm}$.

central Bohai Sea, and thus terrigenous input would not be expected to be as predominant as that observed along the coast ( $\mathrm{Hu}$ et al., 2009; Hu et al., 2013). On comparison to previous studies, TOC/TN ratios in our study were higher with the highest values in the immediate area surrounding the platform. $\delta^{13} \mathrm{C}$ were slightly more negative, and the lower values were also observed around the platform area (Table 1; Fig. c-f; Hu et al., 2009; Liu et al., 2015b). Crude oil is mainly composed of carbon and hydrogen, with very little nitrogen, which would have resulted in much higher TOC/TN ratios, compared to marine and terrigenous organic matter, if a significant fraction remained. Previous studies showed that $\delta^{13} \mathrm{C}$ of crude oil normally range from -32 to $-24 \%$ (Wang et al., 2013b;
Barrie et al., 2016; Muhammad et al., 2017). The ranges and mean values of TOC/TN and $\delta^{13} \mathrm{C}$ in our study indicated the presence of impacts from oil. Spatial distributions of TOC, TOC/TN and $\delta^{13} \mathrm{C}$, however, indicated that the impact might not be related to the oil spill in 2011, but rather operational waste discharges and minor losses of petroleum hydrocarbons from ongoing oil exploration and production activities.

\subsubsection{Heavy metals}

Pollution from both recovered crude oil and production water discharges during oil exploration and production may include petroleum hydrocarbons, heavy metals, naturally occurring radioactive materials and chemical treating agents. Arsenic (As) and mercury $(\mathrm{Hg}$ ) concentrations in sediment were used to trace impacts within the study area from both oil exploration and production activities (e.g. discharge of produced water and drilling muds/ fluids) and the oil spill. As and $\mathrm{Hg}$ are the first and third on the list of hazardous substances prepared by the US Environmental Protection Agency (EPA) and the Agency for Toxic Substances and Disease Registry of the US Department of Health and Human Services. In comparison to other heavy metals (e.g. Ag, $\mathrm{Zn}, \mathrm{Cd}$ etc.), As and $\mathrm{Hg}$ exhibit higher levels of bioaccumulation and toxicity in marine phytoplankton, seaweeds, zooplankton and benthic animals, and especially in animals such as marine mammals, seabirds and sea turtles (Klumpp, 1980; Fisher et al., 1984; Kubota et al., 2001; Kunito et al., 2008; Pan and Wang, 2011; Wang, 2012).

Concentrations of As in sediment at the 17 stations in the study area were higher at $0-5 \mathrm{~cm}$ compared to $6-10 \mathrm{~cm}$. For $\mathrm{Hg}$, however, there was not much difference in the mean concentrations between sediment of $0-5 \mathrm{~cm}$ and $6-10 \mathrm{~cm}$ (Table 1; Fig. $3 \mathrm{~g}-\mathrm{h}$ ). A high concentration was found beside the platform at $0-5 \mathrm{~cm}$, indicating the effects from produced water discharges during the ongoing oil exploration (Fig. $3 \mathrm{i}$ and $\mathrm{j}$ ). In our study, As concentrations were lower than and $\mathrm{Hg}$ concentrations were comparable to previous studies in 2007 and 2009 (Huo, 2011). Considering the inter-annual variations of As and $\mathrm{Hg}$ concentrations in the study area (Table 1), the differences observed in our study were within this variation range (Huo, 2011). Moreover, the concentrations in our study were not higher than other areas in China (such as the Yellow Sea) or in other parts of the world, such as the Black Sea (Guo, 2011; Lan et al., 2014; Bat et al., 2017). The As concentrations in our study approached the standard of Grade I $(<20 \mu \mathrm{g} / \mathrm{g})$, and the $\mathrm{Hg}$ concentrations approached Grade II $(<0.05 \mu \mathrm{g} / \mathrm{g})$ according to the marine sediment quality guidelines established by the P. R. China (GB 18668-2002). Concentrations were also lower than the sediment quality guideline values of Australia (Simpson and Batley, 2016) and much lower than Canadian Interim Marine Sediment Quality Guidelines (ISQGs, $7.24 \mu \mathrm{g} / \mathrm{g}$ for As and $0.13 \mu \mathrm{g} / \mathrm{g}$ for $\mathrm{Hg}$ ). Analysis of the two heavy metals suggested that instead of impacts from the oil spill in 2011, natural background concentrations, and oil exploration and production activities largely accounted for the observed concentration and spatial distribution of As and $\mathrm{Hg}$.

\subsubsection{PAHs}

Sixteen US EPA priority pollutant PAHs were quantified in the sediment samples collected from the 17 stations (Table 1 in supplement). The total concentration in the $0-5 \mathrm{~cm}$ layer ranged from 11.51 to $309.07 \mathrm{ng} / \mathrm{g}$ with an average of $105.72 \mathrm{ng} / \mathrm{g}$, and in the 6-10 cm layer ranged from 7.51 to $368.35 \mathrm{ng} / \mathrm{g}$ with an average of $85.24 \mathrm{ng} / \mathrm{g}$ (Table 1). Although the mean concentration of the 16 PAHs in the surface sediment was slightly higher than in the bottom, the maximum concentration was lower (Table 1 in supplement).

In the absence of an established national sediment quality assessment tool in China, the ISQGs of Canada (Table 1 in 
supplement) were used to provide a comparative assessment on sediment-associated chemicals and their potential concentrations linked to ecological damage. Concentrations of most PAHs were much lower than the ISQGs with the following exceptions. Concentrations of naphthalene were higher than the ISQGs in the surface sediment $(0-5 \mathrm{~cm})$ at three sites and in the bottom sediment $(6-10 \mathrm{~cm})$ at two sites. Acenaphthylene and phenanthrene concentrations in the surface sediment of six sites and bottom sediment of three sites exceeded the ISQGs. Fluorene exceeded the ISQGs at six sites in the surface sediment and in the bottom sediment at two sites. The ISQGs for indeno[1,2,3-cd]pyrene was exceeded at one site in the surface, and at two sites in the bottom sediment layer. It is interesting to note that high values of these five PAH species at $0-5 \mathrm{~cm}$ were for stations $4,9,10,13,14$ and 16 , where the sediments at $6-10 \mathrm{~cm}$ showed high TOC and bottom seawater showed high DIN concentrations (Figs. 2c and 3b; Table 1 in supplement). The PAH concentrations in this study were not substantially higher than that observed in non-spill sites and in our study area before oil spill. Compared with concentrations of the sixteen priority $\mathrm{PAH}$ species in previous studies of surface sediment before and after the oil spill accident, relatively lower values were found in our study (Table 1; Hu et al., 2013; Li et al., 2015), and the values were also found to be close to or higher than in the South
China Sea, higher than in the Northern Yellow Sea and lower than in the Southern Yellow Sea (Table 2 in supplement). The study area, predominantly mud and silt (Hu et al., 2009; Liu et al., 2014b), may not have been an ideal deposition zone for spilled oil (Li et al., 2015). Furthermore, the oil released during the 2011 oil spill accident was reported to have also been dispersed over a large area (the sediment contamination was about $20 \mathrm{~km}^{2}$ by the end of July). Lower molecular weight PAHs may have been biodegraded by benthic microorganisms over a short time period (Kingston, 2002; Atlas and Hazen, 2011; Kappell et al., 2014). Efficient oil degradation activity bacteria, such as $\gamma$-Proteobacteria, have been found in the study area after an oil spill event (Wu, 2013). Petroleum hydrocarbon analysis has also shown that although the oil spill event had affected the adjacent sediments with the petroleum hydrocarbons concentrations increased, the impact had significantly reduced after one year (Liu et al., 2015c).

$\mathrm{PAH}$ isomer pair ratios have been used to determine PAH sources (Yunker et al., 2002; Hu et al., 2013; Li et al., 2015). With the exception of Ant/(Ant + Phe), PAH cross-plot correlations for the ratios of Ant/(Ant + Phe), BaA/(BaA + Chr) and IcdP/(IcdP + BghiP) vs. Fla/(Fla + Pyr) in this study indicated that the source of the PAHs was primarily from combustion rather than a release of petroleum hydrocarbons (Fig. 4). As similar source distributions were
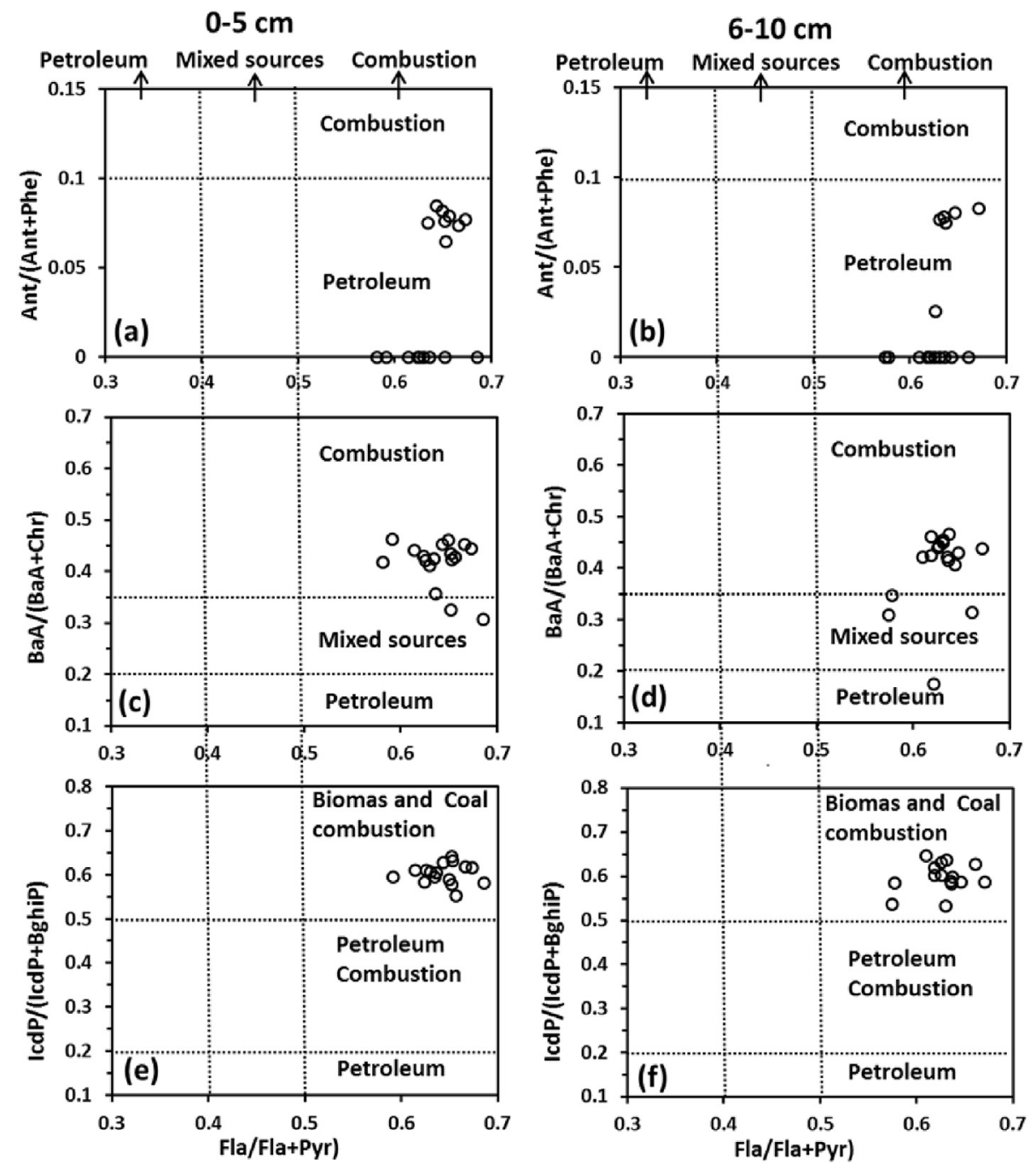

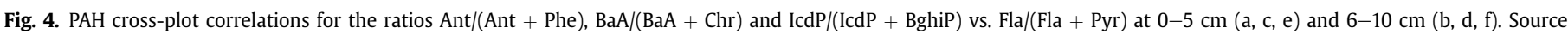
boundary lines are based on Yunker et al. (2002). 
observed for both sampling depths $(0-5 \mathrm{~cm}$ and $6-10 \mathrm{~cm})$, in terms of calculating a mass balance for the oil spilled in 2011, sedimentation and subsequent burial within the sediments did not appear to be a major process.

\subsubsection{Macrobenthos}

Compared to the plankton species, benthos are more susceptible to oil contamination. Benthic organisms are used extensively as biotic indicators of environmental quality because they generally have limited mobility and thus cannot avoid adverse environmental changes. Reductions in the density, biomass and diversity of benthic fauna have been linked to spills of petroleum hydrocarbons in the marine environment (Teal and Howarth, 1984; Kingston, 1992; Lee and Lin, 2013). Previous study of the impact of the 2011 oil spill on macrobenthos revealed that $30 \%$ of the organisms in July, 95\% of the organisms in August and 54\% of the organisms in December 2011 had petroleum hydrocarbon concentrations above background levels. Petroleum hydrocarbon concentrations in mantis shrimp (Orato squillaoratoria) were 4.4 fold higher than background levels (State Oceanic Administration, 2006). Changes in species composition of benthic foraminifera in addition to abnormal development of specimens were observed in 2011 following the Penglai 19-3 spill incident (Lei et al., 2015). The impact of the 2011 spill on macrofauna was analyzed by the comparison of macrobenthos abundance, biomass, Shannon-Wiener indices $\left(H^{\prime}\right)$ and species composition in this study to previous studies before, during and after the oil spill (Table 1 ).

There were 71 macrobenthic species at the 17 stations in the present study. Polychaeta were the most abundant taxon with 46 species (65\% of all the species), followed by Crustacea with 14 species (20\%), Mollusca with 7 species (10\%), Echinodermata with 2 species (3\%), and both Nemertinea and Chordada with only 1 species $(1 \%)$ (Table 3 in supplement). Similar macrobenthic species composition with Polychaeta being the most dominant species was found before and after the oil spill (Table 1; Han et al., 2003; Liu et al., 2014b; Shi, 2014; Zhou et al., 2016). Table 1 also shows that prior to the 2011 spill, Crustacea were the second dominant species and that from 2011 to 2014, Mollusca became the second dominant species, indicated the macrobenthos was towards miniaturization during this period. In our study in 2016, Crustacea exceeded Mollusca and recovered to the second dominant species (Table 1). Macrobenthos abundance showed that the values were decreasing from June 2011 to September 2014 (Shi, 2014; Zhou et al., 2016), and increased in June 2016 in our study (Table 1), indicating the recovery after five years of oil spill. The biomass, however, decreased from 2008 to 2016, and the Shannon-Wiener indices $\left(H^{\prime}\right)$ for 2016 were comparable to previous studies in 1997-1999 and in 2014 in the Bohai Sea (Table 1; Han et al., 2003; Liu et al., 2015d; Zhou et al., 2016). Abundance Biomass Curves indicated that macrofauna communities in the study area in 2014 have been moderately disturbed and that some degree of recovery has occurred (Zhou et al., 2016). Our study indicated significant evidence of further recovery of macrobenthos five years after the spill. However, spatial distributions of macrobenthic abundance, biomass and Hshowed low values in close proximity to the offshore platforms (Fig. 5), suggesting an influence from the offshore platform. Considering the magnitude of the 2011 oil spill and its large impact zone in the sediment, a much more homogenous distribution would be expected if the influence was from the oil spill. Thus, point-source chronic releases of petroleum hydrocarbons during exploration and production operations, such as operational waste discharges, are hypothesized to be the dominant source of pollutants that impacted the macrobenthos populations under study.

\section{Summary}

The present study demonstrated the natural attenuation of impacts from the Penglai 19-3 spill after five years. Values of nutrients, Chl- $a$ and oil concentrations in seawater, and TOC, PAHs, heavy metals, macrobenthic abundance and biomass in sediment compared to that before and after the oil spill accident in previous studies indicated the loss of major environmental impacts from oil spill in 2011 and recovery of biomass. Furthermore, organic matter traced by TOC/TN, $\delta^{13} \mathrm{C}$ and PAH isomer pair ratios indicated a mixture of marine and terrigenous sources as the dominant source of PAHs rather than petroleum. On the other hand, the spatial distributions of the value of chemical and biological factors in seawater (e.g., Chl- $a$ and oil concentrations) and surface sediment (e.g., concentrations of heavy metals and PAHs and TOC, TOC/TN, $\delta^{13} \mathrm{C}$ and microbenthic biomass density) related to the proximity of Platform B and C suggest the presence of near-field impacts from operational waste discharges (e.g. produced water, drilling muds and fluids) associated with offshore exploration and production activities.

While a significant level of recovery within the central region of the Bohai Sea has been observed since the oil spill in 2011, the long term environmental impacts of that event should not be downplayed. For example, following oil spills, the bioaccumulation of petroleum hydrocarbons up the food-chain can endanger a number of organisms and human health (Kingston, 2002). Migration of fish from the Bohai Sea to the Yellow Sea in winter has been affected by the oil spill over an extended period (Guo et al., 2013). The negative influence of the spilled oil is often multi-generational due to detrimental effects on the survival, behavior and reproductive capacity of various organisms (Kocan et al., 1996; Adamas et al., 1999; Pollino and Holdway, 2002). Some harmful components of petroleum (such as PAHs) could also be transported to other regions by currents and mobile organisms following natural dissolution/ dispersion processes that may also include oil-particle interactions, and incorporation into biomass. Suspended particle matter

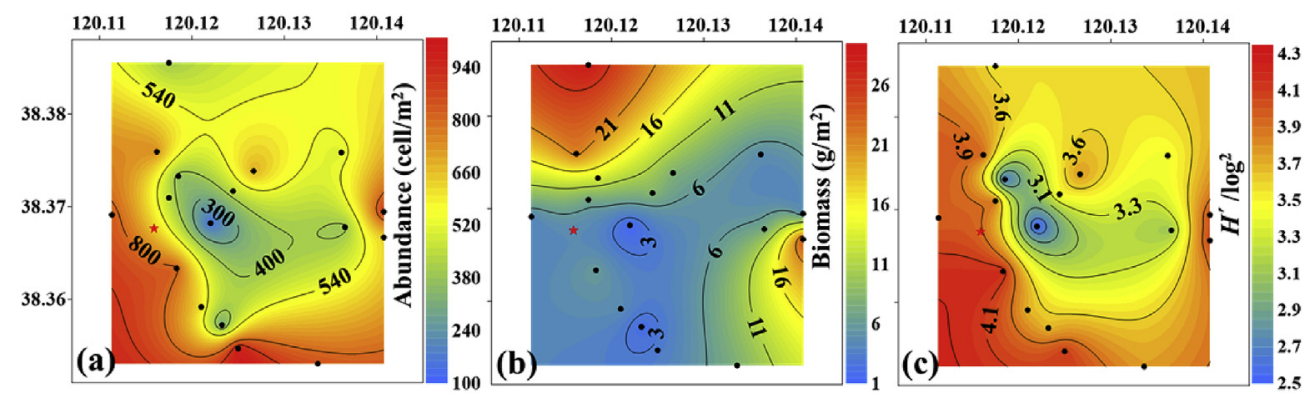

Fig. 5. Spatial distribution of macrobenthic abundance (a), biomass (b) and Shannon-Wiener index $\left(H^{\prime}\right)(\mathrm{c})$. 
contaminated with PAHs within the of Bohai Sea has been known to be transported through the Bohai Strait and deposited within the sediments of the Yellow Sea (Li, 2000).

In summary, in terms of concentrations of the residual oil, the central Bohai Sea has largely recovered from a major oil spill incident in 2011 as the result of spill response operations and natural attenuation. Nevertheless, pollution of the central Bohai Sea region remains an issue of concern due to ongoing chronic releases of contaminant into the system. On the basis of evidence to date, a comprehensive whole ecosystem (end-to-end) approach should be considered in damage assessment, mitigation and resource management following oil spills that considers biophysical (environment, resources, impacts, etc.), economic and social factors.

\section{Declaration of interests}

The authors declare that they have no known competing financial interests or personal relationships that could have appeared to influence the work reported in this paper.

\section{CRediT authorship contribution statement}

Yujue Wang: Formal analysis, Investigation, Data curation, Writing - original draft, Writing - review \& editing, Visualization. Kenneth Lee: Resources, Data curation, Writing - review \& editing. Dongyan Liu: Conceptualization, Methodology, Writing - review \& editing, Supervision, Project administration. Jie Guo: Methodology, Investigation, Resources. Qiuying Han: Methodology, Investigation, Resources. Xihan Liu: Investigation, Resources. Jingjing Zhang: Investigation.

\section{Acknowledgments}

The authors thank all the students and colleagues for their field work at-sea in the Bohai Sea supported by the China Biodiversity Conservation and Green Development Foundation. This work was jointly supported by the Natural Science Foundation of China (41776126 and 41876127), and Joint Funds of Natural Science Foundation of China and Shandong Province (U1706219), and the Multi-Partner Research Initiative Program under Canada's Oceans Protection Plan.

\section{Appendix A. Supplementary data}

Supplementary data to this article can be found online at https://doi.org/10.1016/j.envpol.2020.114343.

\section{References}

Adamas, G., Klerks, P., Belanger, S., Dantin, D., 1999. The effect of the oil dispersant Omni-clean on the toxicity of fuel oil No. 2 in two bioassays with the sheepshead minnow Cyprinodon variegates. Chemosphere 39, 2141-2157.

Atlas, R.M., 1981. Microbial degradation of petroleum hydrocarbons: an environmental perspective. Microbiol. Rev. 45, 180-209.

Atlas, R.M., Hazen, T.C., 2011. Oil biodegradation and bioremediation: a tale of the two worst spills in U.S. history. Environ. Sci. Technol. 45, 6709-6715.

Barrie, C.D., Taylor, K.W., Zumberge, J., 2016. Measurement of compound-specific carbon isotope ratios ( $\delta^{13} \mathrm{C}$ values) via direct injection of whole crude oil samples. Rapid Commun. Mass Spectrom. 30, 843-853.

Bat, L., Ozkan, E.Y., Büyükisik, H.B., Oztekin, H., 2017. Assessment of metal pollution in sediments along sinop peninsula of the Black Sea. Int. J. Mar. Sci. 7, 205-213.

Boutton, T.W., 1991. Stable carbon isotope ratios of natural materials: II. Atmospheric, terrestrial, marine, and freshwater environments. In: Coleman, D.C., Fry, B. (Eds.), Carbon Isotopes Techniques. Academic Press Inc., San Diego, pp. $173-185$.

Bragg, J.R., Yang, S.H., 1995. Clay-oil flocculation and its role in natural cleansing in prince william sound following the exxon valdez oil spill. Exxon valdez oil spill: fate and effects in alaskan waters. In: Wells, P.G., Butler, J.N., Hughes, J.S. (Eds.). American Society for Testing and Materials, Philadelphia, PA, pp. 178-214.

Cai, D.L., Tan, F.C., Edmond, J.M., 1988. Sources and transport of particulate organic carbon in the Amazon River and estuary. Estuar. Coast Shelf Sci. 26, 1-14.

Candler, J.E., Hoskin, S., Churan, M., Lai, C.W., Freeman, M., 1995. In: Society of Petroleum Engineers SPE/EPA Exploration and Production Environmental Conference - Houston, Texas (1995-03-27). SPE/EPA Exploration and Production Environmental Conference - Seafloor Monitoring for Synthetic-Based Mud Discharged in the Western.

Cerniglia, C.E., Perry, J.J., 2010. Crude oil degradation by microorganisms isolated from the marine environment. J. Basic Microbiol. 13, 299-306.

Cheng, L., Wang, Y., Ma, Y., He, J., Liu, A., Song, X., You, L., 2016. The structure of the phytoplankton community in the Laizhou Bay after the oil spills in Penglai 19-3 oilfield. Prog. Fish. Sci. 37, 67-73 (in Chinese, with English abstract).

Cifuentes, L.A., Coffins, R.B., Solorzano, L., Cardenas, W., Espinoza, J., Twilley, R.R. 1996. Isotopic and elemental variations of carbon and nitrogen in a mangrove estuary. Estuar. Coast Shelf Sci. 43, 781-800.

Daly, K.L., Passow, U., Chanton, J., Hollander, D., 2016. Assessing the impacts of oilassociated marine snow formation and sedimentation during and after the Deepwater Horizon oil spill. Anthropocene 13, 18-33.

Ding, G., 2012. Distribution features of oil in sea water and sediment in Auanzhou bay. J. Fujian Fish. 34, 43-47 (in Chinese, with English abstract).

Dubinsky, E.A., Conrad, M.E., Chakraborty, R., Bill, M., Borglin, S.E., Hollibaugh, J.T., Mason, O.U., Piceno, Y.M., Reid, F.C., Stringfellow, W.T., Tom, L.M., Hazen, T.C. Andersen, G.L., 2013. Succession of hydrocarbon-degrading bacteria in the aftermath of the Deepwater Horizon oil spill in the Gulf of Mexico. Environ. Sci. Technol. 47, 10860-10867.

Fingas, M., 2011. Oil Spill Science and Technology: Prevention Response and Clean up. Gulf Professional Publishing, p. 1156.

Fisher, N.S., Bohé, M., Teyssié, J.L., 1984. Accumulation and toxicity of Cd, Zn, Ag, and $\mathrm{Hg}$ in four marine phytoplankters. Mar. Ecol. Prog. Ser. 18, 201-213.

Guo, F., 2011. Distribution of Heavy Metals and Biogenic Elements in the Sediments and Their Ecological Risk Assessment in the East China Sea and Yellow Sea. Master thesis. Jinan University (in Chinese, with English abstract).

Guo, J., Liu, X., Xie, Q., 2013. Characteristics of the Bohai Sea oil spill and its impact on the Bohai Sea ecosystem. Chin. Sci. Bull. 58, 2276-2281.

Han, J., Zhang, Z., Yu, Z., 2003. Macrobenthic species diversity in southern and central Bohai Sea, China. Biodivers. Sci. 11, 20-27 (in Chinese, with English abstract).

Hao, F., Zhou, X., Zhu, Y., Bao, X., Yang, Y., 2009. Charging of the Neogene Penglai 193 field, Bohai Bay Basin China: oil accumulation in a young trap in an active fault zone. AAPG Bull. 93, 155-179.

Hu, B., Li, G., Li, J., Yang, M., Wang, L., Bu, R., 2011. Spatial variability of the ${ }^{210} \mathrm{~Pb}$ sedimentation rates in the Bohai and Huanghai Seas and its influencing factors. Acta Oceanol. Sin. 33, 126-133.

Hu, L., Guo, Z., Feng, J., Yang, Z., Fang, M., 2009. Distributions and sources of bulk organic matter and aliphatic hydrocarbons in surface sediments of the Bohai Sea, China. Mar. Chem. 113, 197-211.

Hu, N., Huang, P., Liu, J., Shi, X., Ma, D., Liu, Y., 2013. Source apportionment of polycyclic aromatic hydrocarbons in surface sediments of the Bohai Sea, China. Environ. Sci. Pollut. Res. 20, 1031-1040.

Huo, S., 2011. Research on Distribution Characteristics and Ecological Risks of Heavy Metal in Surface Sediments of Bohai Sea. Master thesis. Ocean University of China (in Chinese, with English abstract).

Huo, Y., Kuang, W., Zhang, Y., Ji, W., 2011. Analysis and assessment on pollution status by oil in offshore China. Environ. Prot. Sci. 37 (5), 12-15 (in Chinese with English abstract).

Interim Marine Sediment Quality Guidelines (ISQGs), Canadian Sediment Quality Guidelines for the Protection of Aquatic Life, Canadian Council of Ministers of the Environment (CCME), updated 2002.

Kappell, A.D., Wei, Y., Newton, R.J., Nostrand, J.D.V., Zhou, J., Mclellan, S.L. Hristova, K.R., 2014. The polycyclic aromatic hydrocarbon degradation potential of Gulf of Mexico native coastal microbial communities after the Deepwater Horizon oil spill. Front. Microbiol. 5, 205.

Kingston, P.F., 1992. Impact of offshore oil production installations on the benthos of the North Sea. ICES J. Mar. Sci. 49, 45-53.

Kingston, P.F., 2002. Long-term environmental impact of oil spills. Spill Sci. Technol. Bull. 7, 53-61.

Klumpp, 1980. Characteristics of arsenic accumulation by the seaweeds fucusspiralisand ascophyllumnodosum. Mar. Bio. 58, 257-264.

Kubota, R., Kunito, T., Tanabe, S., 2001. Arsenic accumulation in the liver tissue of marine mammals. Environ. Pollut. 115, 303-312.

Kocan, R., Hose, J., Brown, E., Baker, T., 1996. Pacific herring (Clupea pallasi) embryo sensitivity to Prudhoe Bay petroleum hydrocarbons: laboratory evaluation and in situ exposure at oiled and unoiled sites in Prince William Sound. Can. J. Fish. Aquat. Sci. 53, 2366-2375.

Kunito, T., Kubota, R., Fujihara, J., Agusa, T., Tanabe, S., 2008. Arsenic in marine mammals, seabirds, and sea turtles. In: Whitacre, D.M. (Ed.), Reviews of Environmental Contamination and Toxicology. Springer, pp. 31-69.

Lan, X., Mi, B., Li, R., Qin, Y., Wang, Z., Lu, K., 2014. Distribution of heavy metals in surface sediments in the eastern Bohai Sea and the northern Yellow Sea. China Environ. Sci. 34, 2660-2668 (in Chinese with English abstract).

Lee, K., Boufadel, M., Chen, B., Foght, J., Hodson, P., Swanson, S., Venosa, A., 2015. Expert Panel Report on the Behaviour and Environmental Impacts of Crude Oil Released into Aqueous Environments. Royal Society of Canada, Ottawa, ON, ISBN 978-1-928140-02-3.

Lee, K., Stoffyn-Egli, P., 2001. Characterization of oil-mineral aggregates. In: Proceedings of the 2001 International Oil Spill Conference: Global Strategies for 
Prevention, Preparedness, Response, and Restoration, vol. 2, pp. 991-996. March 26-29, At: Tampa, Florida.

Lee, L., Lin, H., 2013. Effects of an oil spill on benthic community production and respirationon subtropical intertidal sandflats. Mar. Pollut. Bull. 73, 291-299.

Lei, Y., Li, T., Bi, H., Cui, W., Song, W., Li, J., Li, C., 2015. Responses of benthic foraminifera to the 2011 oil spill in the Bohai Sea, PR China. Mar. Pollut. Bull. 96, $245-260$.

Li, B., 2000. The Distribution of Polycyclic Aromatic Hydrocarbons and N-Alkanes in the Sediments of Yellow Sea and Bohai. Master thesis. Ocean University of Qingdao (in Chinese, with English abstract).

Li, H., 2013. Numerical Simulation of the Spread-Diffusion Process of Oil Released from Seabed in Penglai 19-3 Oilfield Area. Master thesis. Ocean University of China (in Chinese, with English abstract).

Li, S., Zhang, S., Dong, H., Zhao, Q., Cao, C., 2015. Presence of aliphatic and polycyclic aromatic hydrocarbons in near-surface sediments of an oil spill area in Bohai Sea. Mar. Pollut. Bull. 100, 169-175.

Li, X., Zhao, L., Adam, M., 2016. Biodegradation of marine crude oil pollution using a salt-tolerant bacterial consortium isolated from Bohai Bay, China. Mar. Pollut. Bull. 105, 43-50.

Liu, D., Li, X., Emeis, K.C., Wang, Y., Richard, P., 2015b. Distribution and sources of organic matter in surface sediments of Bohai Sea near the Yellow River Estuary, China. Estuar. Coast Shelf Sci. 165, 128-136.

Liu, L., Wang, Y., Di, B., Liu, D., 2014a. Spatial distribution of chlorophyll $a$ and environmental factors in the Bohai Sea in spring of 2012. Mar. Sci. 38, 8-15 (in Chinese, with English abstract).

Liu, M., Zhang, A., Liao, Y., Fan, D., 2015c. Environmental quality of petroleum hydrocarbons in the surface sediment of the oil and gas exploration zone in the central of Bohai Sea. Mar. Environ. Sci. 34, 12-16 (in Chinese, with English abstract).

Liu, S., Zhang, J., Chen, H., Taabe, T., 2004. Benthic nutrient recycling in shallow coastal waters of the Bohai Sea. Chin. J. Oceanol. Limnol. 22 (4), 365-372.

Liu, X., Fan, Y., Shi, S., Hua, E., Zhang, Z., 2014b. Studies on the species composition and community structure of macrofuna in the Bohai Sea, China. Acta Oceanol. Sin. 36, 53-66 (in Chinese with English abstract).

Liu, X., Guo, J., Guo, M., Hu, X., Tang, C., Wang, C., Xing, Q., 2015a. Modeling of oil spill trajectory for 2011 Penglai 19-3 coastal drilling field, China. Appl. Math. Model. 39, 5331-5340.

Liu, X., Shi, S., Zhou, H., Hua, E., Zhang, Z., 2015d. Macrofaunal diversity and its relationship with environmental factors in the Bohai Sea. Guangxi Sci. 22 540-548 (in Chinese with English abstract).

Maloy, S.R., 2011. A Report by the American Academy of Microbiology. Microbes and Oil Spills. FAQ Washington, D.C., p. 13

Meyers, P.A., 1994. Preservation of elemental and isotopic source identification of sedimentary organic matter. Chem. Geol. 114, 289-302.

Muhammad, S.A., Seow, E.K., Omar, A.K.M., Rodhi, A.M., Hassan, H.M., Lalung, J. Lee, S.C., Ibrahim, B., 2017. Variation of $\delta^{2} \mathrm{H}, \delta^{18} \mathrm{O} \& \delta^{13} \mathrm{C}$ in crude palm oil from different regions in Malaysia: potential of stable isotope signatures as a key traceability parameter. Sci. Justice 58, 59-66.

National Research Council, 2003. Oil in the Sea III: Inputs, Fates, and Effects. National Academies Press, Washington, D.C.

Niu, H., Li, Z., Lee, K., Kepkay, P.V., Mullin, J., 2011. Modelling the transport of Oi-Mineral-Aggregates (OMAs) in the marine environment and assessment of their potential risks. Environ. Model. Assess. 16, 61-75.

Owens, N.J.P., 1987. Natural variations in ${ }^{15} \mathrm{~N}$ in the marine environment. Mar. Bio. 24, 389-451.

Pan, G., Qiu, S., Liu, X., Hu, X., 2015. Estimating the economic damages from the Penglai 19-3 oil spill to the Yantai fihseries in the Bohai Sea of northeast China. Mar. Pol. 62, 18-24.

Pan, K., Wang, W., 2011. Mercury accumulation in marine bivalves: influences of biodynamics and feeding niche. Environ. Pollut. 159, 2500-2506.

Pollino, C.A., Holdway, D.A., 2002. Toxicity testing of crude oil and related compounds using early life stages of the crimson-spotted rainbowfish (Melanotaenia fluviatilis). Ecotoxicol. Environ. Saf. 52, 180-189.
Quigg, A., Passow, U., Daly, K.L., Burd, A., Hollander, D.J., Schwing, P.T., Lee, K., 2019. Chapter 12: marine oil snow sedimentation and flocculent accumulation (MOSSFA) events: learning from the past to predict the future. In: Murawski, S.A., Ainsworth, C., Gilbert, S., Hollander, D., Paris, C.B., Schlüter, M., Wetzel, D. (Eds.), Deep Oil Spills - Facts, Fate and Effects. Springer, pp. 199-224, 608.

Sharma, S.L., 1999. Hydrocarbon Degradation by Microorganisms from the Marine Environment. PHD thesis. University of Pune.

Shi, S., 2014. The Ecological Study of the Macrobenthos in the Bohai Sea, China. Master Thesis. Ocean University of China (in Chinese, with English abstract).

Simpson, S.L., Batley, G.E., 2016. Sediment Quality Assessment: A Practical Guide, second ed. CSIRO Publishing, Australia.

State Oceanic Administration, 2006. Investigation and handling reports of the Penglai 19-3 oil field spill accident. http://www.chinanews.com/gn/2012/06-21/ 3980404.shtml.

Teal, J.M., Howarth, R.W., 1984. Oil spill studies: a review of ecological effects. Environ. Manag. 8, 27-43.

Wada, E., Hattori, A., 1991. Nitrogen in the Sea: Forms, Abundances, and Rate Processes. CRC Press, Boca Raton, p. 208.

Wang, C., Liu, X., Guo, J., Lv, Y., Li, Y., 2018a. Biodegradation of marine oil spill residues using aboriginal bacterial consortium based on Penglai 19-3 oil spill incident, China. Ecotoxicol. Environ. Saf. 159, 20-27.

Wang, H., Wang, B., Dong, W., Hu, X., 2016. Co-acclimation of bacterial communities under stresses of hydrocarbons with different structures. Sci. Rep. 6, 34588.

Wang, H., Wang, C., Lin, M., Sun, X., Wang, C., 2013a. Phylogenetic diversity of bacterial communities associated with bioremediation of crude oil in microcosms. Int. Biodeterior. Biodegrad. 85, 400-406.

Wang, W., 2012. Biodynamic understanding of mercury accumulation in marine and freshwater fish. Adv. Environ. Res. 1, 15-35.

Wang, Y., Liu, X., Sun, Y., Lian, H., Tang, X., 2013b. Identification of oil spill from imported crude oils in China using GC/IRMS. Environ. Forensics 14, 306-311.

Wang, X., Jin, C., Wang, L., Zhang, C., 2018b. Distribution characteristics and influencing factors of particulate organic carbon in the Yellow Sea and the Bohai Sea in summer of 2016. Hai Yang Xue Bao 40, 200-208 (in Chinese, with English abstract).

Wang, Y., Zheng, X., Yu, X., Liu, X., 2017. Temperature and salinity effects in modeling the trajectory of the 2011 Penglai 19-3 oil spill. Mar. Georesour. Geotechnol. 35, 946-953.

Wei, L., Hu, Z., Dong, L., Zhao, W., 2015. A damage assessment model of oil spill accident combining historical data and satellite remote sensing information: a case study in Penglai 19-3 oil spill accident of China. Mar. Pollut. Bull. 91, $258-271$.

Wu, F., 2013. Screening and Identification of Oil-Degrading Marine Bacteria from Spilled Oil in the Bohai Sea and Analysis of Functional Genes. Master thesis. Ocean University of China (in Chinese, with English abstract).

Xu, Q., Li, X., Wei, Y., Tang, Z., Cheng, Y., Pichel, W.G., 2013. Satellite observations and modeling of oil spill trajectories in the Bohai Sea. Mar. Pollut. Bull. 71, 107-116.

Yang, M., 2013. Distribution character of oil in the surface water of Dongshan Bay. J. Fujian Fish. 35, 147-150 (Chinese with English abstract).

Yu, Z., Mi, T., Xie, B., Yao, Q., Zhang, J., 2000. Changes of the environmental parameters and their relationship in recent twenty years in the Bohai Sea. Mar. Environ. Sci. 19, 15-19 (in Chinese, with English abstract).

Yuan, L., Han, L., Bo, W., Chen, H., Gao, W., Chen, B., 2017. Simulated oil release from oil contaminated marine sediment in the Bohai Sea, China. Mar. Pollut. Bull. 118, 79-84.

Yuan, Q., Jiang, M., Wang, Y., 2005. Distribution character of oil in the Changjiang Estuary and adjacent waters. China J. Mar. Environ. Sci. 24, 17-19.

Yunker, M.B., Macdonald, R.W., Vingarzan, R., Mitchell, R.H., Goyette, D. Sylvestre, S., 2002. PAHs in the Fraser River basin: a critical appraisal of $\mathrm{PAH}$ ratios as indicators of PAH source and composition. Org. Geochem. 33, 489-515.

Zhou, Z., Li, X., Chen, L., Liu, X., Li, B., 2016. Long-term effects of Penglai 19-3 oil spill event on the macrobenthic community structure in Bohai Sea. J. Guangxi Acad. Sci. 32, 92-100 (in Chinese, with English abstract). 